\title{
EVALUATION PROGRAM OF THE FOOTBALL ATHLETE DEVELOPMENTS
}

\author{
Safiuddin $^{1}$, Gaguk Margono ${ }^{2}$, Djemari Mardapi ${ }^{3}$ \\ Ibnu Chaldun University ${ }^{1}$ State University of jakarta ${ }^{2}$ State University of jakarta ${ }^{3}$ \\ Safiuddin.uic@gmail.com¹ gagukmargono@unj.ac.id ${ }^{2}$ djemarimardapi@unj.ac.id $^{3}$
}

\begin{abstract}
The aims of this research was to know how far program of football athlete development was effectively successful, how was situation of sport school, whether input is complete supporting this program, whether outputs of this program produced properly without challenge and whether outcomes of this program regenerated correctly without matter, To evaluate this program properly and intensively, so it was used logic model program which consists of situation of sport school, input of this program, outputs of this program and outcomes of this program. Methodology of this research used technique of collecting data by observations, interviews, questionnaires, and documentations study. Analysis of collecting data use triangulation technique which gotten by data resources, namely; organizer/coach and staff of sport school, the athlete, athlete's parents, and society. The results of this research was found and can be concluded that situation of sport school, input and outputs of this program have been being done fairly well, whereas outcomes of this program have been extended impact very well.
\end{abstract}

\section{Keywords: Athlete of Football, Sport School, Logic Model Evaluation Program}

The development of the sports world can not be separated with the progress of joint life of society, nation, and state. Exercise is not only a necessity to maintain body fitness, but has penetrated in all sectors of life. Furthermore, sports achievements can raise the dignity of human beings, individually, in groups, communities, nations and countries.

Sports achievement can be achieved through a systematic, planned, regular, and continuous development process. Achievement of peak performance needs to be elaborated in a comprehensive concept in a tiered form of coaching. In this case, the achievement of the peak of national sport is pursued through a national sports coaching pattern that refers to the pyramid system. The pyramid system in question encompasses cultivation, seeding, performance development to achieve peak performance, with a systematic coaching stage it will produce high sports achievement. Therefore, the government and the managers must with the same intention synergy to design sports coaching program.

Achievement of sports achievement is highly dependent on the application of sports performance system in a country. Bompa (2000: 20) argues that sports coaching systems should be concentrated and be a reference to (1) physical education and national sports organizations in school programs, recreation and sports club clubs and national sports organization structures (2) systems of training exercise applied.

The sports coaching system of emerging achievement in Indonesia is football. Football is a simple and secret game of a good football game is doing the simplest things as well as possible (Batty, 2007: 4). According to Scheunemann (2008: 70), Soedjono (1995: 16), Harsono (2000: 100) The rules applicable in the game of football in official matches are determined by FIFA (Federation International De Football Association). This opinion is reinforced by Clive Gifford; which states that basically a game of football is a simple game. The goal of soccer sports is that players insert the ball as much as possible into the opposing goal and try to keep their own net, so as not to enter the ball (Rahmani, 2014: 99), Irianto (2010: 3).

Important factors in the guidance of soccer athletes are: First physical exercise, Second practice technique, Third tactical exercise, Fourth mental workout. These four fakor are required to 
have by football athletes (Herwin, 2004: 78), Hidayat (2014: 49), Suharto (2000: 102). According to Gheeto TW (2014: 43) that the techniques that must be possessed by a football player are free kick, kicking, stopping, dribbling, heading, tackling, in (throw-in), and keep the goal (goal keeping). AFC (2000: 20) states that the basic training materials for juniors are as follows: (1) dribbling, (2) ball feeling, (3) passing and support, (4) conirolling, (5) running with the ball, (6) tackling, (7) shooting, (8) creative football, (9) goalkeeping, (10) small side games, (11) defending play, (12) attacking play, (13) team organization in 11 vs. 11.

One of the most basic strategies in improving sports in Indonesia, especially in the field of football is to focus and orientate the development of football as early as possible, which is to foster and develop football (sport) for young people from an early age (Harsono 2000: 65). Development and development of sports that are part of efforts to improve the quality of human resources. This effort is directed at improving the physical, mental, and spiritual health of the community; the formation of character and personality, discipline and sportsmanship are high; as well as improvements in achievements that can inspire national pride

National sports coaching involves important components other than identified coaching paths. Components in the national sports coaching system are: 1) objectives, 2) management, 3) manpower factors, 4) athletes, 5) infrastructure, 6) structure and content of the program, 7) learning resources, 8) methodology, 9) evaluation and research, as well as 10) funds (Harsuki, 2003: 37). Conceptually, the component components that are identified are very important for the implementation of the process of macro-level sports training at national level or club level micro level.

The evaluation process should be done comprehensively so that the results of the form of information must be completely valid and reliable. This information is then used to construct a coaching program This means that evaluation should be done thoroughly to find out the supporting elements of a program. A program is not just a single activity that can be completed in a short time, but is a continuous activity for implementing a policy. Therefore, sports coaching program needs to be evaluated so that sport achievement can be known increase from year to year

By evaluating the program will be found the fact of implementation of public policy in the field that the results can be positive or negative. Professional evaluations will result in objective findings that are valid findings and with very little errors. By karana it needs to be determined appropriate evaluation method to develop sports coaching program.

One of the implementation of the coaching process is a club under the branch manager (Pengcab). In the process of guidance to the highest achievement, sports club (club) is in a strategic place, because it is in the leading position and become the spearhead of achievement coaching. In addition to the club as one of the pengenggra sports coaching process, the government also conducts sports coaching through formal schools namely junior and senior high school.

The sportsmanship program to improve sports performance among learners has been implemented through various activities. These activities include: sports coaching, sports pemassalan, pernanduan talent, improving the quality of coach / trainer sports and development of sports facilities / facilities. These activities are also supported by the construction of various sports facilities and infrastructure in schools. such as the First High School (JSS) and Senior High School (SMA) Ragunan.

Football athletes coaching program at SMA Negeri Ragunan has been done since 1977, but see the current conditions are still not optimal. This is due to the guidance is still not paying attention to aspects of its management. The picture shows the condition of prerequisite and post-coaching which is still there are weaknesses, namely:

1. There has been no evaluation of the extent to which the successful implementation of football athletes coaching program in SMA Negeri Ragunan. 
2. Guidance has not produced graduates who are capable of better than before. The reality on the ground shows that after following the coaching there has been no maximum performance improvement or achievement.

3. There has been no evaluation of post-athletes following the coaching of football athletes (impact).

Coaching, education and training can be successful if athletes can receive and experience the right knowledge, skill, and attitude. This ability is provided by the appropriate instructor / trainer and the use of methods and media specifically designed to improve performance / competence. This can only be known when program evaluation is conducted continuously and programmatically.

According to Donald and James (2006: 17) there are several reasons why training evaluation is necessary, namely: (1) to determine the effectiveness of a training program and obtain information to develop future training programs; (2) to determine whether training programs forwarded, modified, or discontinued, (3) to provide concrete evidence of the existence of training institutions by showing their contribution to the goals and objectives of the company. Thus, evaluation of the implementation of coaching is done to ensure the occurrence of learning process that leads to increased competence needs to be done. Evaluations should be conducted periodically to enable repeatable and sustainable coaching

Evaluation by Hogan (2004: 2), Stufllebeam (1994: 9), McDavid (2006: 11) is one of the links in the system of coaching, education and training. According to Djaali and Muljono (2008: 1) evaluation is the process of assessing something based on predetermined criteria or objectives which are then followed by decision making on the object being evaluated, so according to Djemari Mardapi (2008: 8), evaluation is one of a series of activities in improving quality, performance or productivity of an institution unit in implementing a program, an institution in implementing its program must conduct a series of activities by improving the quality, performance and productivity.

Evaluation from the time of its implementation can be at the beginning of the planning process, in the middle of the implementation process, at the end of the implementation of the training, or after the participants are at work (Purwanto, 1999: 1), In the process of implementation of the training, evaluation is intended to seek input from participants, instructors, and organizers about classrooms, teaching and learning, materials availability, accommodation, and consumption all beneficial to the improvement of ongoing education.

To see the effectiveness of football athletes coaching program in SMA Ragunan, it is necessary to evaluate the reaction of participants / athletes on the implementation of educational programs. This evaluation is to know the change of knowledge level, skill, and positive attitude of participant after following program of football athlete coaching. The most important thing that is expected to be seen is the change in worker behavior of the participants / athletes after returning to the home or club environment, and the increasing impact on the productivity level of the work unit.

The program evaluation model used in this evaluation study is the logic model because it has the ability to measure and assess a more comprehensive coaching program and be able to show a series of causal relationships. Logic Model is a description of how a program is implemented, a road map that emphasizes how a program should work, what activities should be done before doing other activities so that the expected results can be achieved (Barkman, 2000: 4), McDavid (2006: 41). According to Milica (2011: 11), Frechtling (2007: 25), Rusdi Akbar (2013: 37), component of logic model result of evaluation model development consisting of six that is: situation, input, activities, outputs, outcomes, external factor, six these components are interrelated and form a systematic work step. According to Powell who dikutif by McCawley (2002: 11) that the element logic model can be identified with 4 (four) stage evaluation of the program ie situation, input, output and outcomes.

\section{METHOD}

The evaluation research of this coaching program is conducted at special school of sportsman (SKO) that is at SMA Negeri Sport Ragunan South Jakarta and at area of origin and also club which shaded athletes. Evaluation time will be conducted from November to January 2017. 
This evaluation study used case study method with logic model. This logic model of evaluation dominates assessment and discloses cause and gives in-depth information about events during the program, decomposed comprehensively both internally and externally, this model gives a response to something to be achieved.

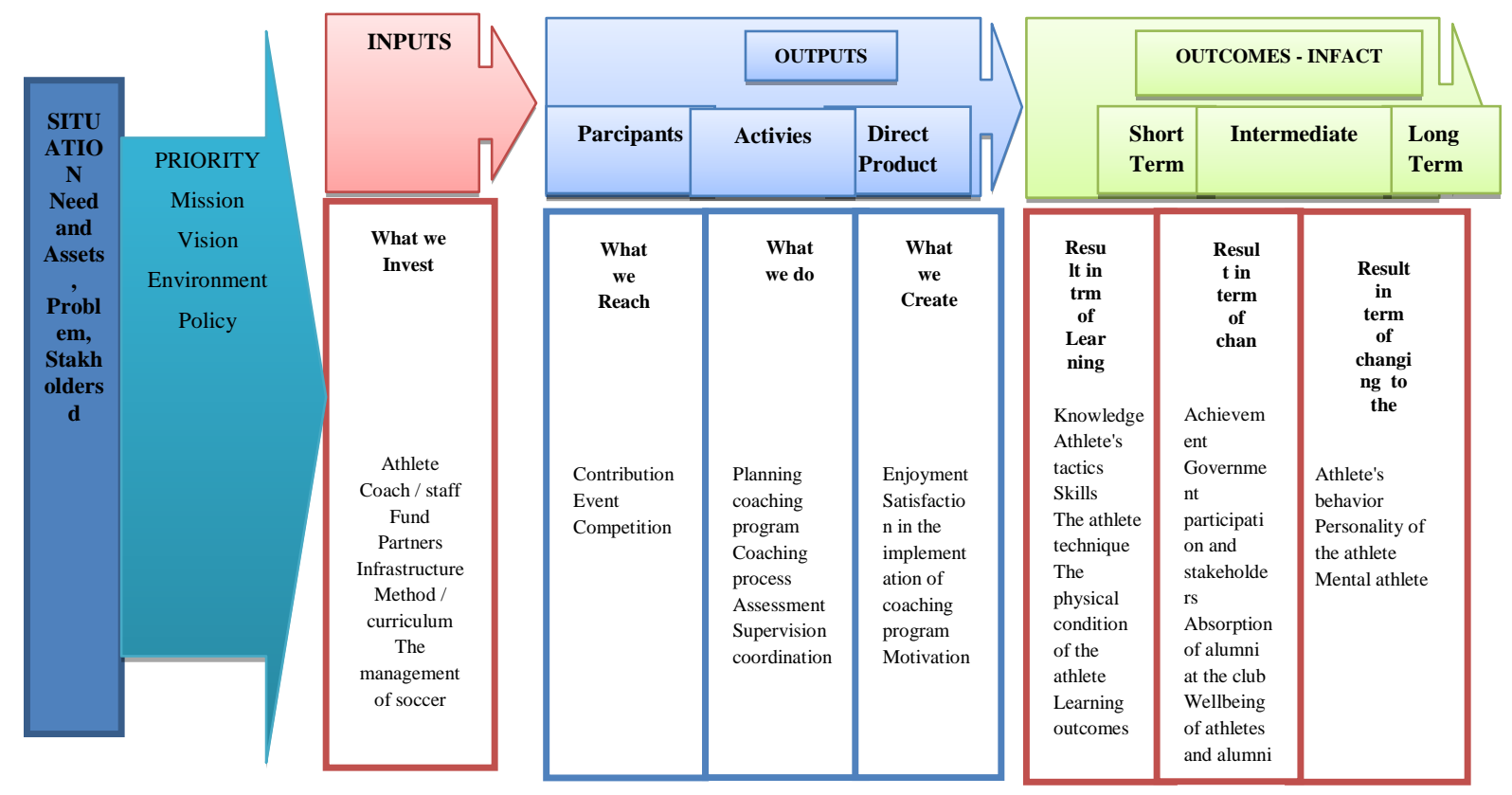

Figure Design Model Logic Model Evaluation

Data collection techniques are sourced from primary and secondary data. Primary data is data obtained directly from research at SMA Negeri Sport Ragunan. Secondary data is taken from the existing data in the form of policies, operational guidance / standardization of programming. Data collection in research at SMA Negeri Sport Ragunan this, implemented through several instruments; observation, interview, questionnaire, and documentation.The data analysis technique used in this research is Description and Analysis of Data, Interpretation, Judgment, and Recommendation, where the technique of analysis was developed by Patton (Stufflebeam and Shinkfield, 2007: 441).

Description and analysis describes the data of research findings into narrative text. The data obtained is categorized according to subject matter made in matrix form so it is easy to see patterns of relationship one data with other data. With the data descriptions, it will make it easier to understand and analyze what happens to the program, then plan the next work based on the results of the analysis.

Interpretation: Interpretation of data is an attempt to interpret the data that can be taken by way of reviewing the symptoms based on his point of view. This interpretation study involves several important things in a research that is in the form of discussions, conclusions, and implications such as: flashbacks of major findings and how research questions are answered, researcher reflection on the meaning of data, researcher views contrasted with literature review (theoretical), and suggestions for further research.

Judgment: is to provide value to the data after the analysis and interpreted. Determining worthiness or value means solving the extent to which data are able to provide a descriptive statistical value in a report. Data needs to be organized, organized, and organized in the form of whether the outcome is positive or negative, good or bad, is needed or not?. And does the data meet the standards that researchers want?

Recommendation: after the process of data interpretation by synthesising the data that has been collected while continuing to perform the verification process to the conclusions that have been 
made tentatively, which then can be formulated a more appropriate conclusion. The final conclusion will be a recommendation and a decision of this study (Patton, 1997: 307).

\section{Evaluation of school situation}

\section{RESULT}

Evaluation of the situation by all assessors above can be clarified through the table presented below:

Situation Assessment Table by All Respondents

\begin{tabular}{|c|c|c|c|}
\hline \multirow{2}{*}{ No } & \multirow{2}{*}{ Responden } & \multicolumn{2}{|c|}{ SITUATION } \\
\hline & & $\%$ & Category \\
\hline 1 & Manager & $83.6 \%$ & Medium \\
\hline 2 & Alumni & $85.0 \%$ & Medium \\
\hline 3 & Society & $96.3 \%$ & Good \\
\hline 4 & Athlete & $85.0 \%$ & Medium \\
\hline 5 & Athlete SKO & $84.1 \%$ & Medium \\
\hline 6 & Athlete PPOP & $86.3 \%$ & Medium \\
\hline & $\%$ & $86.7 \%$ & \\
\hline & Category & & Medium \\
\hline \multicolumn{4}{|c|}{$\begin{array}{l}\text { Decision: } \\
\text { The school environment situation is good enough, } \\
\text { Aspects that need to fix is: } \\
\text { - Internal and external environment } \\
\text { - Spatial arrangement } \\
\text { - Implementation policy } \\
\text { - Coaching programs should be tailored to the obj }\end{array}$} \\
\hline
\end{tabular}

In the table presented above, it can be seen that globally the school complex situation is in good condition, as well as the vision of the school mission and the foundation of good enviroment, the internal and external environment of the school and the wider space is good enough, as well as the policy of organizing and the suitability between the program and the goals and objectives to be achieved.

Based on the comparison of success criteria of soccer coaching program situation, it is clear that the situation of the school of football athlete at SMA Negeri Sport Ragunan Jakarta still does not meet the criteria. This is because the party who runs the school athletes football training has not maximized condition of the school situation in a good / adequate and conducive.

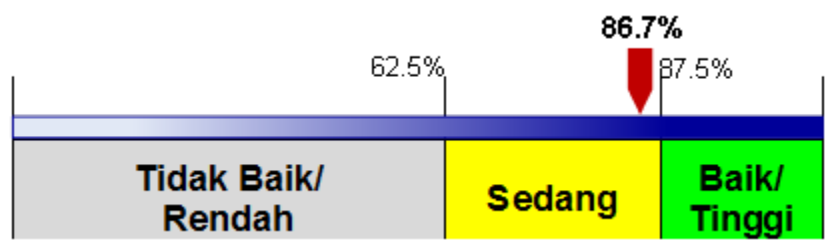

Figure Categorization of Successful Situations by All Appraisers

\section{Input Evaluation}

The results of questionnaires from all respondents, managers / trainers, parents, communities, alumni and athletes can be illustrated as follows:

Table of Input Assessment by All Respondents

\begin{tabular}{|l|c|c|c|c|}
\hline No & Respondents & INPUT & \% & Category \\
\hline
\end{tabular}




\begin{tabular}{|l|l|l|l|l|l|l|l|l|l|}
\hline & \\
\end{tabular}

From the results of this interview it can be seen that the trainer has done his job well in applying the method of coaching athletes that have been systematized.

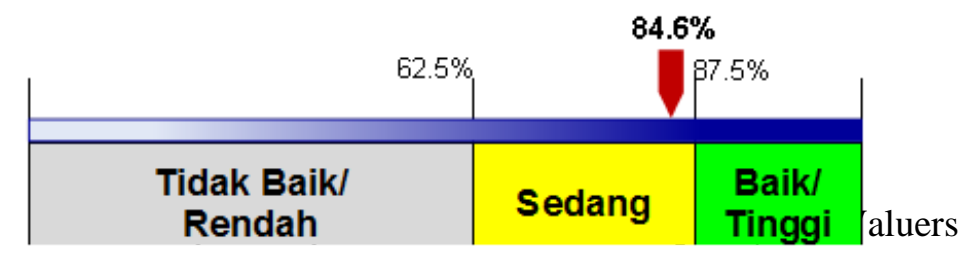

While the facilities and infrastructure (facilities) is an integral part of input, supporting athletes coaching program. Complete facilities and adequate to support the success of football athletes coaching program at the State Sports complex Ragunan Jakarta. Football athletes coaching facilities include; learning support tools, soccer coaching facilities and football training equipment.

In connection with the above, then it can be said components of infrastructure facilities athletes coaching program works quite well, as presented below:

Table of Infrastructure Appraisal by All Respondents

\begin{tabular}{|c|l|c|c|c|c|c|}
\hline \multirow{2}{*}{ No } & \multirow{2}{*}{ Respondents } & $\begin{array}{c}\text { Learning } \\
\text { Support } \\
\text { Tools }\end{array}$ & $\begin{array}{c}\text { Facilities Of } \\
\text { Coaching } \\
\text { Program }\end{array}$ & $\begin{array}{c}\text { Football } \\
\text { Training } \\
\text { Equipment }\end{array}$ & \multirow{2}{*}{$\%$} & \multirow{2}{*}{ Category } \\
\hline 1 & Society & $60.2 \%$ & $50.8 \%$ & $60.3 \%$ & $\mathbf{5 7 . 1 \%}$ & Not Good \\
\hline 2 & Athlete & $68.1 \%$ & $67.5 \%$ & $73.1 \%$ & $\mathbf{6 9 . 9 \%}$ & Medium \\
\hline 3 & Athlete SKO & $73.3 \%$ & $68.0 \%$ & $76.6 \%$ & $\mathbf{7 2 . 8 \%}$ & Medium \\
\hline 4 & Athlete PPOP & $61.1 \%$ & $66.9 \%$ & $68.4 \%$ & $\mathbf{6 5 . 9 \%}$ & Medium \\
\hline & $\mathbf{\%}$ & $\mathbf{6 5 . 7 \%}$ & $\mathbf{6 3 . 3 \%}$ & $\mathbf{6 9 . 6 \%}$ & $\mathbf{6 6 . 4 \%}$ & \\
\hline & Category & Medium & Medium & Medium & & Medium \\
\hline
\end{tabular}

Decision:

Based on input sub-evaluation, infrastructure of athlete coaching program has medium 
actuality.

Aspects that need to be addressed are

1. Learning support tools

- Sound system or wireles, LCD, Computer, technology, Multimedia

- Worship room and library

2. Coaching program facilities

- Playstation (PS game football) and futsal field should be provided

- Football field and toilet / toilet / WC must be repaired and added in number, also provided synthetic field

- Office space, dormitory, fitness, sports equipment, means of consumption infrastructure and public kitchen should be addressed

3. Football training equipment

- Statues should be provided

- Other equipment repaired

Judging from the graph above indicates that athletes and the public assess the components of infrastructure facilities athletes coaching programs still do not support the athlete coaching activities. Of course automatically the athlete coaching program that run can not take place smoothly because there are some obstacles infrastructure suggestions in achieving the success of athletes coaching program.

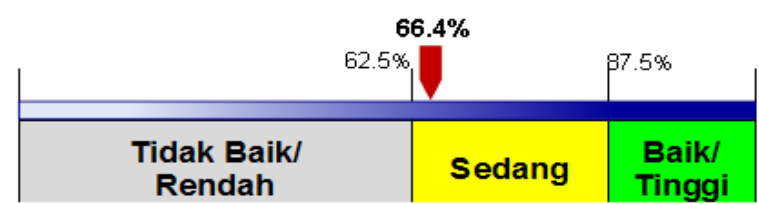

Figure Categorization of Infrastructure Success by All Appraisers

\section{Evaluate Outputs}

Based on the results of questionnaires by all respondents about the outputs showed a fairly high number. This is seen from the table presented below:

Table of Output Assessment by All Respondents

\begin{tabular}{|c|c|c|c|c|c|c|}
\hline \multirow{2}{*}{ No } & \multirow{2}{*}{ Resondents } & \multicolumn{3}{|c|}{ OUTPUT } & \multirow{2}{*}{$\%$} & \multirow{2}{*}{ Category } \\
\hline & & Participant & Activities & Direct Product & & \\
\hline 1 & Manager & $86.0 \%$ & $82.1 \%$ & $90.8 \%$ & $83.8 \%$ & Medium \\
\hline 2 & Society & $85.4 \%$ & $81,0 \%$ & $80.6 \%$ & $82.1 \%$ & Medium \\
\hline 3 & Parents & $89.8 \%$ & $85.6 \%$ & $86.4 \%$ & $86.9 \%$ & Medium \\
\hline 4 & Alumni & $90.0 \%$ & $89.8 \%$ & $88.9 \%$ & $89.7 \%$ & Good \\
\hline 5 & Athlete & $85.3 \%$ & $84.2 \%$ & $87.5 \%$ & $85.7 \%$ & Medium \\
\hline 6 & Athlete SKO & $83.6 \%$ & $83.9 \%$ & $90.6 \%$ & $86.3 \%$ & Medium \\
\hline 7 & Athlete PPOP & $87.5 \%$ & $84.7 \%$ & $83.3 \%$ & $84.9 \%$ & Medium \\
\hline & $\%$ & $86.80 \%$ & $84.47 \%$ & $86.87 \%$ & $86.1 \%$ & \\
\hline & Category & Medium & Good & Medium & & Medium \\
\hline
\end{tabular}

Decision:

Based on the output evaluation, the program of football athlete training has a medium or good enough accuracy.

Aspects that need to be burdened are:

1. Participant:

- Athletes should often be involved in competitions at national and international levels

- Competitions / leagues are held regularly and tiered

2. Activities:

- Trainers should plan variation of exercise program

- Implementation of supervision and supervision should be done in a planned and 
sustainable by all parties, especially managers

- Application of athlete coaching strategies and methods should be improved so that the results can be in accordance with PSSI standards, AFC and even FIFA standards

3. Direct Product

- Athletes should often be given motivation, because many athletes are saturated

The table presented above shows that the managers / trainers, athlete's parents, the community, alumni, athletes, athletes SKO Kemenpora and PPOP athletes assess the outputs of the football athletes coaching program, the success outs of athletes. The results of the assessment of outputs about participant, activities and direct product, obtained a very good result. Surely this has not brought an optimal impact for the continuity of the program.

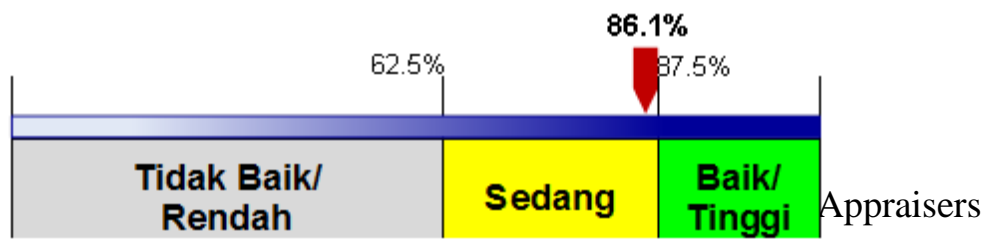

These findings show that the outputs issued from the football athletes coaching program at the State Sports High School Ragunan Jakarta is quite good. This indicates that the outputs of athletes and coaches' contributions to events and competitions at national or international levels are still not optimal, as well as training activities and results obtained by athletes are not yet categorized as successful

\section{Evaluasi Outcomes}

Based on the results of questionnaires by all assessors about outcomes showed a fairly high number. This is seen from the table presented below:

Outcome Appraisal Table by All Respondents

\begin{tabular}{|c|l|c|c|c|c|c|}
\hline \multirow{2}{*}{ No } & \multirow{2}{*}{ Respondents } & \multicolumn{3}{|c|}{ OUTCOMES } & \multirow{2}{*}{$\%$} & \multirow{2}{*}{ Category } \\
\cline { 3 - 6 } & & $\begin{array}{c}\text { Short- } \\
\text { term }\end{array}$ & Medium-term & Long-term & & \\
\hline 1 & Manager & $88.8 \%$ & $85.6 \%$ & $76.6 \%$ & $\mathbf{8 2 . 6 \%}$ & Medium \\
\hline 2 & Society & $100 \%$ & $95,8 \%$ & $82.3 \%$ & $\mathbf{8 9 . 4 \%}$ & Good \\
\hline 3 & Parents & $96.2 \%$ & $95.5 \%$ & & $\mathbf{9 5 . 8 \%}$ & Good \\
\hline 4 & Alumni & $84.7 \%$ & $89.6 \%$ & $81.0 \%$ & $\mathbf{8 4 . 3 \%}$ & Medium \\
\hline 5 & Athlete & $92.6 \%$ & & & $\mathbf{9 2 . 6 \%}$ & Good \\
\hline 6 & Athlete SKO & $95.3 \%$ & & & $\mathbf{9 5 . 3 \%}$ & Good \\
\hline 7 & Athlete PPOP & $88.9 \%$ & & & $\mathbf{8 8 . 9 \%}$ & Good \\
\hline \multicolumn{2}{c}{$\%$} & $\mathbf{9 2 . 4 \%}$ & $\mathbf{9 1 . 6 \%}$ & $\mathbf{8 0 . 0 \%}$ & $\mathbf{8 8 . 0 \%}$ & \\
\hline \multicolumn{2}{|c|}{ Category } & Good & Good & Medium & & Good \\
\hline
\end{tabular}

\section{Decision:}

Based on outcomes evaluation, coaching program of athlete of football has high actuality. Aspects that need to be addressed are:

Form of local and central government attention to the welfare of alumni athletes and trainers

From visualized graphs, it is seen that outcomes of athletes coaching programs consist of; short term, medium term and long term has been successfully implemented.

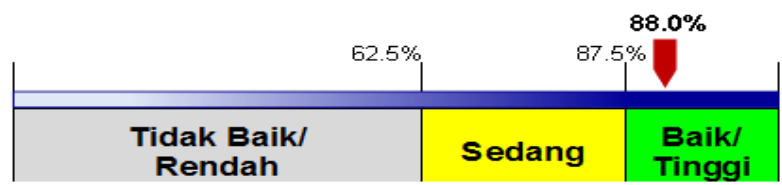




\section{Figure Categorization of Successful Situations by Society}

From these findings it appears that the impact of short and medium jagka from football athletes coaching program has progressed and categorized well. This suggests that outcomes of athlete coaching programs have gained significant success helping athletes achieve achievement.

\section{Situation}

\section{DISCUSSION}

The criteria for the success of the evaluation of the situation is the existence of the policy / basis / foundation of the program implementation in accordance with the goals, objectives, vision and mission and create a conducive situation / situation in implementing the program of football athletes training. Under such conditions, the program of football athlete training can run success in the effort to foster athletes. Based on the findings in the field, determine the decision that the evaluation of the situation is in the category of actuality or moderately good / adequate. All aspects of the situation need revamping and improvement.

The findings indicate that creating a conducive atmosphere of confusion still needs to be improved, due to the wide variety of ethnic, religious, racial and customary athletes' origins. Every inhabitant of the athlete's athletic complex must be of high tolerance, because if this is not done well in creating a conducive situation, it will inevitably impede the implementation of athletes development activities. So that the program athlete football coaching is applied will not achieve success optimally even the program will run haltingly and difficult to obtain success.

Based on the observations made, it can be seen that the external environment of the school is in good condition. The community and the inhabitants of the athlete school complex are side by side quite well, but on the other hand still need to be improved the security system and its comfort.

The vast conditions of school space can also determine the success of football athletes coaching program. If the circumstances of school space freely, then the activities undertaken athletes in undergoing athlete training will feel comfortable without obstacles so that the program can run well. Automatically the program can meet the success criteria of the program. On the other hand, when there is insufficient and narrow space for school space, this will make the athlete's development activity slow, and it is difficult to achieve the program's success criteria.

Based on the results of observation shows that the condition of the wider space of the center of coaching athletes football SMA Negeri Sport Ragunan still need to be in good spatial management, given the land is not so large where the number of residents and many people around that often use sports facilities to make wide space feels cramped.

Based on the findings in the field, managers feel the need for policy synchronization made by central and local government, considering the Ragunan sports school is used by more than two agencies. Where selamaini central and local governments overlap and rely on each other, so in the end the athlete coaching program is disrupted. Like the improvement of athlete training facilities and infrastructure, the central government handed over improvements to the regions, while relying on the central government. Such a policy must be resolved and resolved, in order for athletes to succeed and achieve.

From the components of the school situation that has been described above, it can be concluded that the linkage between these components is strong enough to support the activities of athletes coaching program. If one of the components is not good enough / adequate, then the athlete coaching program will experience obstacles in meeting the criteria of the success of the program set. Therefore, to achieve the target of the success criteria of the program, the components of the school situation that are less good / adequate need to be repaired immediately. 


\section{Input}

The success criteria for input evaluation are the ability of athletes to be above average, high coach competence, sufficient funds, good partner contributions, adequate infrastructure, good program curriculum and good sports management. With such conditions, then the program of football athletes who run can be said to succeed in the effort to build football athletes.

Based on the findings in the field, determined that the input evaluation is in the category of topicality or good enough / adequate. Where 2 sub aspect of input have entered in successful category while 4 more still need improvement and repair.

Based on the criteria of the success of the football athlete coaching program, the athletes received by the Ragunan Sports State Senior High School must have an above-average qualification. The research findings reveal that the criteria or minimum limit of new athlete's input should have 1, 2, 3 achievement at the provincial or national champion and even international champion, this shows that the manager has set a strict recruitment system so that new athletes will be more achievers again when later following the coaching program. Findings based on interviews indicate that the selection process is done online or online, after which send administrative files, medical tests, physical tests and interviews. An important part of using online recruitment is that avoiding cheating in athletes' acceptance and outcomes is better and can reflect the true athlete's ability.

Standard trainers and coaching staff also plays an important role in efforts to meet the target of the success criteria of football athletes coaching program at SMA Negeri sport Ragunan Jakarta. The result of observation and documentation in the field found that the higher education level of the trainer from SMA / equivalent and have expertise in accordance with the field of science, the quality of the trainers has also been proven, has brought its players Berjaya become champion in national level and even bias compete in international level. Therefore, the criterion of competency criteria of trainers has met the criteria of successful athlete development program that is set, but still must be upgraded to remain more achievers again.

The next discussion is the funds used to finance the activities of athletes coaching program. Funds have an important and sensitive role in the process of coaching athletes, as they require substantial funds. If funds are insufficient for the financing of the program, then automatically the coaching program must be hampered, so budget planning and realization of budget usage must be adjusted properly. The findings in the field revealed that the operational funds derived from the state budget for athletes coaching program activities are still inadequate, in addition to the amount of funds needed for the improvement of facilities and infrastructure, for basic needs are still lacking, for example funds for eating athletes still do not meet the standards that should at meals by athletes, as well as funds to meet medicinal needs for athletes who are sick. Thus, operational funds still do not meet the criteria of program success.

The findings of the field show that the fact that the partners have contributed to overcome the funding for program financing, one of which is the Brebes district government contributed to the SKO Kemenpora players in the soeratin championship event of Central Java and National zone, where the players have proved it by becoming champion soeratin Central Java and National Soeratin champion. To finance such a large competition is required of very large funds, if not assisted by partners and only rely on funds from the state budget, it can be estimated that athletes can not show their abilities to the maximum and become the champion and boast the name of the State. There are even some players who have contributed internationally, one of them is Egi Maulana Vikri's brother, he became the dominant player in world championship in Spain and became a World Champion, this success is inseparable from the role of partners.

Contribution from partners still needs to be improved. one of the roles of experts and community support in general, because the contribution of partners to smooth the process of coaching athletes is still in the medium category, meaning the help of partners to smooth the process 
of athlete development still needs to be addressed so that the success criteria of football athletes coaching program can be fulfilled.

Based on the findings in the field and the results of the study documentation shows that the preparation of methods by trainers made within a period of one year and must be agreed by the manager, the planning method is tailored to the goals to be achieved that is achievement at national and international level. The preparation of this method seems to work as described above.

The method of coaching athletes soccer applied in the State Sports SMA Ragunan refers to the standard of PSSI, AFC even adopted from the theory put forward by Timmo Scheunemann which in fact its curriculum made standard FIFA, technically the method is applied very well and categorized so high the success of the program has been achieved.

The next discussion about sports management, based on the success criteria of football athlete training program, the management has an important role in helping the success of athletes coaching program, which is good time management, attendance manager, coach, staff and athletes high, administration and school performance is good.

Every day of practice, coaches and athletes are always disciplined in carrying out an exercise program, if any athlete or coach who arrives late without clear training, will automatically get the sangki and late exercise and even bias interfere with other exercise programs. The administration of the coaching program is already good as the administrative process when the athlete will go home, there must be a permit from the boarding house, and known to the parents. Likewise with competitions and tournaments to be followed by athletes must be with the knowledge of the manager either Kemenpora or Sports Department DKI. But there is still a need to fix about the performance of managers, so the overall management of athletes coaching programs are moderate, still need to be addressed so that the success criteria of football athletes coaching program can be fulfilled.

Based on the observation that found that the supporting facilities of athletes supporting facilities is complete enough, it still needs a little improvement so it does not hamper the athlete development activities ie sound system or wireless, LCD, computer, multomedia technology, worship room and library, therefore these learning support tools still need to be addressed so that the bias meets the criteria of success.

In addition, the facilities of athletes coaching program is still moderate or sufficient enough, even there are still not yet available even damaged such as futsal field that must be immediately provided, while the football field which number 3 field condition is damaged, if in the rain field will be inundated unusable and the soil mud is very disturbing to the exercise program, if the dry mud makes the field harder causing frequent injuries to the athlete, this is really very disturbing and hinders the exercise program.

The condition of the toilet room was very worrisome conditions, coaches and athletes feel very uncomfortable when using it. The condition of other facilities requires a little improvement, thus from these findings, the state of the training program facilities are moderate or sufficient enough, so it still does not meet the criteria of program success. Football training equipment is also in good enough condition or sufficient, athletes only need a statue to manambah collection of existing equipment in addition to other files in the fix or added in number.

Based on the description of the above input components, it can be concluded that the components are mutually require one with another and have the same interests in an effort to support the implementation of football athletes coaching program at SMA Negeri sport Ragunan Jakarta. So that athlete coaching program can gain optimum success. When this is not realized it is definitely difficult for this athlete coaching program to achieve satisfactory results. So therefore the constraints that exist in the input components above, need to be provided, repaired, fixed properly so that the success of this athlete coaching program can be achieved immediately.

\section{Output}


The success criteria of output evaluation is the contribution of athletes in the event and national and international football competition, the implementation activities of both categories and direct products in the form of pleasure, satisfaction, motivation of athletes when undergoing coaching program in good condition. With such conditions, then the output of football athletes coaching program that run can be said to succeed.

Based on the findings in the field, determined that the evaluation of output is in the category of actuality or moderately good / adequate means still need improvement and improvement. Actually, the findings in the field, the participant aspect is quite good, where the athletes are involved in the event / competition at the national level such as POPWIL, POPNAS, the king of Yogyakarta and Soeratin. Even at international level, athletes contribute to Beijing Cup championship, Subroto Cup in India, SKO competition in Thailand and U15 championship in Spain. But the competition is expected by the PSSI is a legal competition and regular and tiered, so that the process of athlete's ability evaluation can be measured systematically.

Further discussion of the activities of football athletes development, diaman field findings indicate that the implementation of training activities activities quite well including learning support tools include semester program, this year has been agreed by the coach and the manager when the contract process is done. The active learning of athletes when the implementation of the coaching program is also quite good because the interest of athletes learning in the implementation process of coaching program is quite high.

The standard of fulfillment of consumption intake and nutritional needs of athletes is good especially for PPOP football team of DKI Jakarta, nutrient intake is very good. However, for SKO Kemenpora football team is still below the standards, as expressed by one of the board of kemenpora that nutritional intake for athletes has not been maximal still below the standards that should, and yet there is no nutritional needs of athletes. This problem must be solved immediately, that is by allocating more funds from the government, then the catering managers must be highly qualified.

Furthermore, the schedule and execution of supervision must be planned, scheduled with good supervision report document, this is done so that the coaching program can be well controlled. The promotion and degradation system of athletes is good, if there are athletes who are not progressing then they will be degraded and returned to their parents if there is an athlete whose development is very good, then the manager / coach will promote it to the national soccer team.

From field observation also found that still need improvement to support the success of coaching activity that is coach have to make planning of variation of exercise program so that athletes do not feel saturation during exercise activity, application of strategy and method of athlete development should be improved so that result can be according to standard of PSSI, AFC even the FIFA standard so that the implementation activities of coaching can be categorized successfully.

The results of field observations on direct products show that athletes already feel the pleasure and satisfaction in the implementation of the program so that athletes are more motivated to undergo coaching, but with routines that take place every day and the same environment makes athletes often feel saturation in implementing the program, psychology to provide motivation in addition to trainers / staff themselves, maybe this should be a little improvement so that direct products are good and can meet the criteria of program success.

From the output components described above, it can be concluded that in order to meet the target of the success criteria of the soccer athlete development program, the participation, activities and direct products of athlete coaching should be improved even better so that the coaching program of soccer athletes at the State Sports High School Ragunan Jakarta is achieved optimally and meets the target of program success criteria.

\section{Outcome}


The success criteria for outcome evaluation is the impact of short, medium and long term is good. With such conditions, the coaching program athletes who run football can be said to succeed. Based on the findings in the field, indicating that the evaluation of outcome is in the category of topicality or good enough / adequate.

The short-term impact of the athlete's football coaching program is that athletes have been able to implement their own knowledge (tactics), apply the skills (techniques), physical condition of athletes seseuai PSSI standards and the average value of athletes learning test results are high, sydah graduation certificates are quite good. The findings in this field indicate that athletes already feel there is a significant increase in terms of tactics, techniques and physical conditions. This is also evidenced by the results of athlete development reports that are always carried out by the team of coaches. When compared to athletes of his age, athletes at SMA Ragunan are above average.

Furthermore, the findings of mid-term outcomes from the soccer athlete coaching program are the achievement of medium-term outcomes are considered good, including: behavior change athletes and behave / behave as an athlete classified so champion with the spirit of togetherness of athletes after undergoing mentoring and mental enhancement of athletes classified as pertained good.

The aspect of the assessment of long-term outcomes is also quite good, where the achievement of athletes / alumni at the national level even at the international level, the quantity / number of alumni absorbed in the club are also numerous, but the alumni welfare is not guaranteed as well as the attention of local governments, center, quite good. Actually this improvement has started to be seen where the alumni of Ragunan is a bone, when they graduate high school, athletes can get into the TNI, POLICE, government agencies, even university clubs are happy to recruit these athletes, one factor is the physical condition of the athletes has been tested and is above average, but this still must continue to be encouraged and there needs to be agreement between the manager and related institutions / stakeholders. One of them is done by Kemenpora with the State University of Jakarta who signed MOU Memorandum on achieving athlete achievement, where the athletes can continue to study at university while the cost of education is borne by the university and the cost of life is borne by kemenpora.

In outcomes components of athlete coaching program described above, it can be concluded that the components are already considered good although there is still a need to be addressed. Because these components can not be separated from each other and support each other in the implementation of athletes coaching program so that the success criteria of the program can be fulfilled. If this is not immediately addressed, it will lead to various obstacles in achieving the success of football athletes coaching program in this school.

\section{CONCLUSION}

Based on the results of the evaluation and discussion, furthermore it can be drawn conclusions on all aspects of evaluation that includes the evaluation of the situation, input, output and outcome evaluation for the implementation of football athletes coaching program at the State Sports High School Ragunan. In detail can be described, as follows:

\section{Situation}

The situation of SMA Negeri Sport Ragunan complex can be drawn conclusion in good enough / adequate condition, covering situation of internal environment, situation of external environment and situation of wide area of movement. So the situation of school complex with good enough condition, automatically still not fulfill the criteria of success of coaching program of soccer athlete, not yet fulfill the criterion of situation to become the training center of nation athlete athlete expected, specially to print athletes with national and even international standard capability . This indirectly still has not helped the launching of a government program to become a place for gold generation children to be athletes at the pinnacle of achievement. 


\section{Input}

Input in the football athlete coaching program at the State Sports High School Ragunan this, concluded not yet support the smooth process of athlete coaching program activities with good / adequate. Inputs in this program include; athletes, trainers, funds, partners, means of infrastructure, methods and management of athletes coaching programs. With the excellent input / adequate is the competence of trainers and coaching methods, then functioned very well in this program, then by itself the inputs that exist in this program has helped in facilitating the process of athlete coaching activities. However, adequate inputs / sufficient athletes, funds, partners, infrastructure and program management, have not functioned well in this program, so this input has not contributed to the success of football athletes.

\section{Outputs}

The next conclusion is that the outputs of the athlete coaching program at SMA Negeri Sport Ragunan have not contributed very well / sufficiently, so it must be done immediately and improvement especially the participation of athletes should often be involved in competition / league which is legal and regular at national and international level. Then the activity of the training program should be made varied, carried out consistent supervision. Then the athletes should be given seing motivation so as not to experience saturation while following an athlete coaching program. In other words, through participation, activity and direct good product, the outputs issued have not experienced a very significant success. This is certainly with the support of the situation and input program of football athletes training is good enough, the athlete coaching program has not been able to obtain success in accordance with the success criteria of athletes coaching program established

\section{Outcomes}

Then, the outcomes / impacts of the athlete coaching program generated have altered the knowledge (tactics), skills (techniques) and athlete's physical condition, behavior, personality, mental athletes are getting better. Nanum achievement, participation of local and central government, and the welfare of alumni still need to be refined and addressed. Thus, the outcomes of the football athlete coaching program have undergone significant progress and progress, both for athletes, alumni, parents, managers / coaches, community and even government.

With the support of the situation, the input and output of football athletes coaching program which is only categorized good enough, then give impact very good outcome, athlete coaching program can get success according to success criteria of athlete coaching program that set. So it should all stakeholders give serious attention to this football athletes coaching program.

\section{REFERENCES}

Asian Footbal Confederation. (2000). "C” Certificate Coaching Manual. Kualalumpur: AFC.

Atmodiwirio, Soebagio. (2002). Manajemen Pelatihan. Jakarta: Ardadizya Jaya.

Barkman, Susan J. (2000). Utilizing The Logic Model for Program Design And Evaluation. IN: Purdue University.

Bidang Pembinaan Prestasi. (1997). Sistem Pembinaan Atlet Berprestasi. Jakarta: Komite Olahraga Nasional Indonesia.

Bompa, Tudor O. (2000). Total Training for Young Chammpion. Illionis: Champaign Human Kinetic.

Brenner, David. (1989). Successful Soccer . Elangland: Sackvile Books Ltd.

Bucher, Charles A., dan March L. Krote. (1993). Management of Physical Education and Sport. St Louis Missiouri: Mosby Year Book, Inc.

Cummings, Rick. (2006) "What If: The Counterfactual in Evaluation Program." Evaluation Journal Australia, 6(2).

Delevic, Milica. (2011). Guide to the Logical Framework Approach. Belgrade: GSM Advertising d.o.o.

Departemen Pendidikan Nasional. (2001). Petunjuk Pelaksanaan Pembinaan dan Pengembangan Klub, Bakat dan Minat Siswa. Jakarta: Departemen Pendidikan Nasional. 
Direktur Jenderal Olahraga Departemen Pendidikan Nasional. (2002). Pedoman Mekanisme Koordinasi Pembinaan Olahraga Kesegaran Jasmani dan Kelembagaan. Jakarta: Departemen Pendidikan Nasional.

Djaali dan Pudji Mulyono. (2004). Pengukuran dalam Bidang Pendidikan. Jakarta: Program Pascasarjana Universitas Negeri Jakarta.

Drowatzky, John N. (1981). Motor Learning, Principles, And Practices. New York: Burgess Publishing Company.

Frechtling, Joy A. (2007). Logic Modeling Methods in Program Evaluation. San Fransico: Jossey Bass.

Gallahue, David L. (1989). Understanding Motor Development: Infants, Children, Adolescents. Indiana: Benchmark Press, Inc.

Good, Thomas L. dan Jere E. Brophy. (1990). Education Psychology. New York: Longman Group Ltd.

Harsono. (2000). Coaching dan Aspek Psikologis dalam Coaching. Jakarta: CV. Tambak Kusuma. . (2004). Perencanaan Program Latihan. Jakarta: PT. Remaja Rosdakarya.

Harsuki. (2003). Manajemen Olahraga. Jakarta: PT. Raja Grafindo Persada. . (2003). Perkembangan Olahraga Terkini, Kajian Pakar. Jakarta: PT. Raja Grafindo Persada.

Hernandez, Ruben Acosta. (2003). Managing Sport Organization. Illionis: Human Kinetics.

Hidayat, Syarif. (2014). Pelatihan Olahraga, Teori dan Metodologi. Jakarta: Graha Ilmu, 2014.

Hogan, Lance R. (2004). "The Historical Development of Program Evaluation: Exploring The Past and Present." Online Journal of Workforce Educational and Development.

Howell, Reet A. dan Maxwell L. Howell. (1991). Conceps of Physical Education. Auckland: The Jacaranda Press.

Kamars, H. M. Dachnel. (2005). Administrasi Pendidikan Teori dan Praktek. Padang: Universitas Putra Press.

Kelley, Dennie. R., Patricia A. Beitel, Joy T. DeSensi, dan Mary Dale Blanton. (1994). "Undergraduate and graduate sport management curricular models: A perspective." Journal of Sport Management.

Keputusan Kepala Lembaga Administrasi Negara No. 358/IX/6/4/2000 tentang Kriteria Penunjang Widyaiswara.

Kiram, Yanuar. (1992). Belajar Motorik. Jakarta: DEBDIKBUD Pendidikan Tinggi Proyek Pembinaan Tenaga Pendidikan.

Kirkpatrick, Donald L., dan James D. Kirkpatrick. (2006). Evaluating Training Programs: The Four Levels. San Fransisco: Berret-Koehler Publisher, Inc.

Komite Olahraga Nasional Indonesia. (2005). Panduan Pembinaan Olahraga Prestasi. Yogyakarta: Komite Olahraga Nasional Indonesia DIY. . (1997). Pedoman Pembentukan dan Pembinaan Klub Olahraga. Jakarta: Komite Olahraga Nasional Indonesia Pusat.

Lutan, Rusli, Supandi, Iwan Setiawan, Imam Hidayat, Kunkun K. dan Wiramihardja. (2005). Manusia dan Olahraga. Bandung: ITB dan FPOK-IKIP Bandung.

Magill, Richard A. (1985). Motor Learning Conceps \& Applications. Iowa: WM. C. Brown Publishers.

Mardapi, Djemari. (2008). Teknik Penyusunan Instrumen Tes dan Nontes. Yogyakarta: Mitra Cendekia Press.

McCawley, Paul F. (2002). The Logic Model for Program Planning and Evaluation. Moscow: University of Idaho Extension.

McDavid, James C., dan Laura R. I. Hawthorn. (2006). Program Evaluation and Performance Measurement. New Delhi: Sage Publications.

Mielke, Danny. (2007). Dasar-Dasar Sepak Bola. Jakarta: Pakarnya Pustaka.

Muchtar, Remmy. (1992). Olahraga Pilihan Sepakbola. Jakarta: Direktorat Jenderal Pendidikan Tinggi Proyek Pembinaan Tenaga Kependidikan.

O'She, M., dan G. Watson. (2007). "Academic Learning for Sport Management Students: The Learning Through Engaged Practice." Journal of Cooperative Education.

Papaioannou, Alkistis, Thanos Kriemadis, P. Alexopoulus, O. Vrondou, dan N. Kartakoullis. (2009). "The Relationship between Human Resource Empowerment and Organization Performance 
in Football ClubsLearning Through Engaged Practice." International Journal of Sport Management Recreation and Tourism.

Pasolong, Harbani. (2010). Kepemimpinan Birokrasi. Bandung: Alfabeta.

Patton, Michael Quinn. (1997). Utilization Focused Evaluation. London: Sage Publications.

Purwanto dan Atwi Suparman. (1999). Evaluasi Program Diklat. Jakarta: STIA-LAN Press.

Satria, M. Haris., Tandiyo Rahayu, Soegiyanto K. S. (2012). "Evaluasi Program Pembinaan Olahraga Sepakbola di Sekayu Youth Soccer Academy (SYSA) Kabupaten Musi Banyuasin Sumatera Selatan." Journal of Physical Education and Sports.

Scheunemann, Timo S. (2012). Kurikulum dan Pedoman Dasar Pembinaan Sepakbola Indonesia. Jakarta: PSSI.

Soegijono. (1994). Pembinaan Prestasi Olahraga Garuda Mas Menuju tahun 2000. Semarang: IKIP Semarang.

Soegiyanto. (1997). "Pengembangan Modul Pembinaan Olahraga Usia Dini," Makalah disajikan pada konferensi Nasional Pendidikan Jasmani dan Olahraga, IKIP Bandung..

Stark, J. S., dan A. Thomas. (1994). Assessment and Program Evaluation. Massachusetts: Nedham Heights, Simon \& Schuster Custom Publishing.

Stoner, James A. F. (1992). Manajemen, terjemahan Alfonus Sirait Jakarta: PT. Gelora Aksara Pratama Erlangga.

Stufflebeam, D. L., dan Anthony J. Shinkfield. (2007). Evaluation Theory, Model, and Aplications. San Fransico: Jossey Bass.

Stufflebeam, D. L. (2003). "The CIPP Model Evaluation." Presented at The 2003 Annual Conference of The Oregon Program Evaluators Network (OPEN). Massachusetts: Nedham Heights, Simon \& Schuster Custom Publishing.

Sudjana, Djuju. (2008). Evaluasi Program Pendidikan Luar Biasa. Bandung: PT Remaja Rosdakarya.

. (2008). Evaluasi Program Pendidikan Luar Sekolah Untuk Pendidikan Nonformal dan Pengembangan Sumber Daya Manusia. Bandung: PT. Remaja Rosdakarya.

Sudjana, Nana. (1999). Penilaian Hasil Proses Belajar Mengajar. Bandung: PT Remaja Rosdakarya.

Sugiyono. (2008). Metode Penelitian Kuantitatif Kualitatif dan R\&D. Bandung: Alfabeta. .(2009). Metode Penelitian Pendidikan. Bandung: Alfabeta.

Suharto. (2000). Pedoman dan Modul Pelatihan Kesehatan Olahraga Bagi Pelatih Olahragawan Pelajar. Jakarta: Depdiknas Pusat Pengembangan Kualitas Jasmani.

Suherman, Wawan S. (2002). Manajemen Olahraga. Yogyakarta: Fak Ilmu Keolahragaan.

Sukadiyanto. (2005). Teori dan Metodologi Melatih Fisik. Jakarta: Peteknis.

Sukantaka. (2000). Administrasi Pendidikan Jasmani. Yogyakarta: Fak Ilmu Keolahragaan UNY.

Syarifuddin, Aip. (1990). Pendidikan Jasmani dan Kesehatan. Jakarta: PT Gramedia Widiasarana Indonesia.

Tangkudung, James. (2006). Kepelatihan Olahraga, Pembinaan Prestasi Olahraga. Jakarta: Cerdas Jaya.

Umar, Husein. (2008). Desain Penelitian MSDM dan Perilaku Karyawan, Paradigma Positivistik dan Berbasis Pemecahan Masalah, Jakarta: Rajawali Press.

Undang-Undang Nomor 3 Tahun 2005 tentang Sistem Keolahragaan Nasional.

Widoyoko, S. Eko Putro. (2009). Evaluasi Program Pembelajaran Panduan Praktis Bagi Pendidik dan Calon Pendidik. Yoyakarta: Pustaka Pelajar.

Zaini, Muhammad. (2006). Pengembangan Kurikulum. Surabaya: eLKAF.

Zhang, Guili, Nancy Zeller, Robin Griffith, Debbie Metcalf, Jennifer Williams, Christine Shea, dan Katherine Misulis. (2011). "Using the Context, Input, Process, and Product Evaluation Model (CIPP) as a Comprehensif Framework to Guide the Planning Implementation, and Assessment of Service-Learning Programs." Journal of Higher Education Outreach and Engagement. 